\title{
A Study to Investigate Teaching Efficacy Among Prospective Teachers
}

\author{
Saghir Ahmad \\ PhD Scholar, Institute of Education and Research, University of the Punjab, Lahore Pakistan
}

\author{
Dr. Ayesha Batool \\ Assistant Professor, The Department of Education, Lahore College for Women University, Lahore Pakistan
}

\begin{abstract}
Teacher is one of the most important ingredient of any education system. The aim of this study was to identify the teaching efficacy among prospective teachers. The study was quantitative and survey type in nature. Prospective teachers participated as sample of study. Questionnaire was used to collect data from research participants. Perceptions were explored on five point likert scale. The scale was validated from relevant experts and reliability checked by applying Cronbach's Alpha. The reliability value was 0.894 , which is statistical significant. The researchers went to the selected department for the data collection. The researchers granted permission letter from the institution of education research. They elaborated the main purpose of the study to respondents by keeping the ethical consideration. Descriptive and inferential statistical techniques were applied to analyze the data. Mostly teachers were agree that they have a good grasp of teaching approaches that help them to maintain students' learning motivation. Their teaching methods are very effective in helping students learning and they know how to teach a new concept so that students will master it quickly. Male and female teachers have no difference in their perceptions regarding teaching efficacy. Prospective teachers may focus on teaching methods and deliver lectures and content by adopting relevant methods.
\end{abstract}

Keywords: Prospective teachers, teaching efficacy, and relevant methods.

DOI: $10.7176 / \mathrm{JEP} / 10-16-08$

Publication date:June $30^{\text {th }} 2019$

\section{Introduction}

Education in the 21 st century has turned into a high stakes game in which educators and managers alike are intensely examined for learners' achievement. Maybe nobody feels the compression of this investigation more than educators. Instead of certainty and strengthening, numerous teachers feel inadequacy and do not comprehend the mental condition of students. The future achievement of the education system is reliant upon many things, one of which is teachers' belief that have and their associates to convey advantageous and satisfactory guidance to enable their students to perform better and actively. Student achievement is heavily dependent upon teacher efficacy. Teaching efficacy is responsible for students' academic satisfaction (Ross \& Bruce, 2007).

Lee (2002) expressed that "teacher beliefs and practices are heart of student achievement" (p. 67). Educator efficacy, the desire that one has the ability and capacities to achieve learner learning, is key to academic change. Inspiration is a structure square of instructor efficacy, effects performance, commitment, and retention of teacher. Besides, it is due to motivation, separated through the dimensions of efficacy that educators determine what sort of an effect they will have on students. Thus, it seems that teaching efficacy and academic achievement of students both are interrelated (Tucker, Porter, Reinke, Herman, Ivery, \& Mack, 2005).

As indicated by social intellectual theory, human idea and attitude cannot be completely comprehended except if it is inspected inside the social framework wherein it works. Teachers are in charge of conferring information to students who fluctuate in learning styles, behavior, and dimensions of inspiration. Teachers define beliefs in teaching process about their abilities to create these ideal student results. Though these viability convictions reflect individual encounters with understudies, these convictions additionally create as an element of input from the more extensive school social condition contained different instructors and directors (Bandura, 1986).

Self-viability is a multidimensional term, different in level, inclusive and quality oriented (Bandura, 1997). Viability convictions of people can be founded on errands in a specific area that lie on a continuum from easy to respectably hard to very burdening. Moreover, people may feel efficacious in a wide scope of activities or just in specific areas, and these beliefs of efficacy may be feeble, solid, or fall in the middle. Efficacy beliefs are not a fixed characteristic of a person. In actuality, these beliefs may change given a person's assessment of his performances and achievements in a given field in time. The connection between individuals' past encounters, feeling of adequacy, and future exhibitions is guided by their elucidation of their exhibitions as opposed to the genuine presentation itself. In this way, individuals' apparent self-adequacy is not an evaluation of their abilities, but instead a conviction about what they can or cannot achieve under different conditions, given the aptitudes 
they do have. Self-viability convictions, thusly, perform as an arbitrator between people's information of their aptitudes and their future activities. Thus, when contrasted with their non-efficacious compliments, strong people are less inclined to abstain from challenging activities that may surpass their capacities, are bound to consume more exertion and continue longer notwithstanding trouble, and are more averse to harp on close to home deficiencies or see issues as more troublesome than they truly may be.

Miskel, McDonald, and Bloom (1983, as refered to by Lee in 2002) described instructor adequacy to teacher practices which they finished up emphatically influence student: (a) accomplishment, (b) inspiration, (c) self-idea, and (d) generally energy for school. If teacher efficacy, the belief that one can realize learning, is helpless against the political plan of institutionalization of appraisal, which enhances the stress of the activity and results in great educators who forsake the profession, at that point school change must wind up focused on methodologies to hold and further grow and introduce great teachers who have strong self-efficacy beliefs. Teachers may pay attention to their abilities and polish with the passage of time. The high and low adequacy impact and predicts the person's performance level. High efficacy instructors go up against instructive difficulties and eagerly try different things with recently created showing methodologies while low adequacy educators see procedures, for example, separation, as an unmanageable issue. Generally speaking, educators of strong efficacy beliefs invest more energy checking their students and can keep up their commitment in sly ways. This behavior also exhausts the certainty, confidence, commitment, and hazard taking endeavors of students who might be uncertain of themselves (Barkley, 2006).

\section{Significance of Study}

This research provides the basic information regarding teacher efficacy. This research provides the teacher efficacy framework as a guide to unravel and investigate key factors that might help and drive the successful identification of teacher efficacy in school education in particular in the educational sector as a whole. The educators and practitioners can understand the teacher efficacy. It is helpful for the future researchers who want to conduct more research on the teacher efficacy.

\section{Research Objectives}

The following were the objectives of the study to:

1. Identify the perceptions of prospective teachers about teaching efficacy.

2. Identify the difference in the perceptions of prospective teachers about teaching efficacy on the basis of their demographic variables.

\section{Research Methodology}

Research design describes plans and procedures for research which cover the decisions from broad assumptions to detailed methods of data collection and analysis. In this study, a quantitative approach applied to conduct survey research. The population for this study consisted of prospective teachers of elementary department of Institute of Education and Research Lahore. Convenient sampling technique was used to select the sample. After specifying the population the researchers draw a sample. The data were collected from two hundred male and female prospective teachers from elementary department. The instrument developed in this study was a questionnaire which was designed to obtain as much relevant information in achieving the objectives of the study. Questionnaire was prepared to check the teaching efficacy of teachers. Questionnaire contained different factors and each factor had various statements. Five point likert type scale was used. There were two sections in the questionnaire. The first section consisted of the demographic information which includes department, qualification, age and gender. The second section consisted of statements related to statements of teaching efficacy. The scale was validated from relevant experts and reliability checked by applying Cronbach's Alpha. The reliability value was 0.894 , which is statistical significant. The researchers went to the selected department for the data collection. The researchers granted permission letter from the institution of education research. They elaborated the main purpose of the study to respondents by keeping the ethical consideration. Data analysis is the process of transforming raw data into numbers and applying statistical tools, and aims to describe, summarize, compare data as well as discover knowledge. Quantitative research allows the researcher to summarize large bodies of data and interpret the numbers by using various statistics. In this study, the data were analyzed using the descriptive statistics (mean, standard deviation, frequencies and percentage). Independent sample t-test and One Way ANOVA tests were applied in inferential statistics to check the significance difference. 
5. Data Analysis

The detail of data analysis is given below.

Table 1

Demographic Information of Research Participants

\begin{tabular}{lccc}
\hline Demographic Variable & & Frequency & Percent \\
\hline Gender & Male & 60 & 30.0 \\
& Female & 140 & 70.0 \\
Age & Total & 200 & 100.0 \\
& $20-25$ & 8 & 4.0 \\
& $26-30$ & 46 & 23.0 \\
Qualification & $31-35$ & 146 & 73.0 \\
& Total & 200 & 100.0 \\
& Intermediate & 12 & 6.0 \\
Teachers & Bachelor & 71 & 35.5 \\
& Master & 117 & 58.5 \\
& Total & 200 & 100.0 \\
\end{tabular}

Table 2

Teachers' Responses about Teaching Instruction

\begin{tabular}{llll}
\hline Instruction & $M$ & $S D$ & Interpretation \\
\hline I have a good grasp of teaching approaches that help me to maintain students' & 4.13 & .896 & Agree \\
learning motivation. & & & \\
My teaching methods are very effective in helping students learn. & 3.95 & .835 & Agree \\
I know how to teach a new concept so that students will master it quickly. & 3.89 & .916 & Agree
\end{tabular}

Table shows the mean and standard deviation of the teachers' responses about the Teaching Instruction that mostly teachers were agree that they have a good grasp of teaching approaches that help them to maintain students' learning motivation $(M=4.13, S D=.896)$, their teaching methods are very effective in helping students learning $(M=3.95, S D=.835)$, and they know how to teach a new concept so that students will master it quickly $(M=3.89, S D=.916)$. It is concluded that teaching instruction is important for the teacher. Many essential factors of Teaching Instruction are used by teaches and majority of the teachers are agree with these statements.

Table 3

Teachers' Responses about Teaching Discipline

\begin{tabular}{lccc}
\hline Discipline & $M$ & $S D$ & Interpretation \\
\hline I am effective in making rules and regulations for students. & 4.00 & .962 & Agree \\
I have very effective classroom management skills. & 3.95 & .884 & Agree \\
I find it easy to make my expectations clear to students. & 3.89 & .921 & Agree \\
I can communicate to students that I am serious about getting appropriate & 3.92 & .887 & Agree \\
behavior. & 3.61 & 1.119 & Agree \\
I get out the students from class when they disturb and make a noise. & & & \\
\hline
\end{tabular}

Table shows the mean and standard deviation of the teachers' responses about the teaching discipline that mostly teachers were agree that they are effective in making rules and regulations for students $(M=4.00, S D$ $=.962)$, they have effective classroom management skills $(M=3.95, S D=.884)$, they find it easy to make their expectations clear to students $(M=3.89, S D=.921)$, they can communicate to students that they are serious about getting appropriate behavior $(M=3.92, S D=.887)$, and they get out the students from class when they disturb and make a noise $(M=3.61, S D=1.119)$. It is concluded that teaching discipline is important for the teacher. Majority of the teachers are agree with discipline statements.

Table 4

Teachers' Responses about Teaching Guidance

\begin{tabular}{lllc}
\hline Guidance & $M$ & $S D$ & Interpretation \\
\hline I am good at counselling students. & 3.96 & .893 & Agree \\
Students come to me for help when they have problems in their daily life. & 3.92 & .989 & Agree \\
I understand students' psychological needs easily. & 3.93 & .945 & Agree \\
I am able to help students with emotional problems adjust better in life. & 3.93 & .983 & Agree \\
\hline
\end{tabular}

Table shows the mean and standard deviation of the teachers' responses about the Teaching Guidance that mostly teachers were agree that they are good in counselling of students $(M=3.96, S D=.893)$, Students come to them for help when they have problems in their daily life $(M=3.92, S D=.989)$, they understand students' 
psychological needs easily $(M=3.93, S D=.945)$, and they are able to help students with emotional problems adjust better in life $(M=3.93, S D=.983)$. It is concluded that teaching guidance is important for the teacher and students.

Table 5

Teachers' Responses about External Matters

\begin{tabular}{lrrr}
\hline External & $M$ & $S D$ & Interpretation \\
\hline There are some students who would not behave no matter what I do. & 3.74 & 1.058 & Agree \\
A teacher is limited in what he/she can achieve in student discipline because of & 3.80 & .944 & Agree \\
the current values in society. & & & \\
I find some students to be impossible to discipline effectively. & 3.83 & .959 & Agree \\
\hline
\end{tabular}

Table shows the mean and standard deviation of the teachers' responses about the External Matters that a group of teachers were agree that there are some students who would not behave no matter what I do $(M=3.74$, $S D=1.058)$, A teacher is limited in what he/she can achieve in student discipline because of the current values in society $(M=3.80, S D=.944)$ and they find some students to be impossible to discipline effectively $(M=3.83$, $S D=.959)$. It is concluded that external matters is important for the teacher.

Table 6

Male and Female Difference about Teaching Efficacy

\begin{tabular}{|c|c|c|c|c|c|c|c|}
\hline Efficacy & Gender & $N$ & Mean & $S D$ & $t$ & $d f$ & Sig. \\
\hline \multirow[t]{2}{*}{ Instruction } & male & 60 & 12.2000 & 1.95544 & .969 & 198 & .334 \\
\hline & female & 140 & 11.8786 & 2.22629 & & & \\
\hline \multirow[t]{2}{*}{ Discipline } & male & 60 & 19.6833 & 3.17560 & .812 & 198 & .418 \\
\hline & female & 140 & 19.2500 & 3.57474 & & & \\
\hline \multirow[t]{2}{*}{ Guidance } & male & 60 & 16.0667 & 2.19295 & 1.196 & 162.852 & .234 \\
\hline & female & 140 & 15.5929 & 3.28041 & & & \\
\hline \multirow[t]{2}{*}{ External } & male & 60 & 11.3667 & 2.33591 & .006 & 198 & .995 \\
\hline & female & 140 & 11.3643 & 2.61487 & & & \\
\hline
\end{tabular}

Table shows that an independent sample t-test was applied to compare the teaching instruction, teaching discipline, teaching guidance, external matters and teaching efficacy scores of male and female teachers. There was no significant difference in teaching instruction scores of male $(M=12.2000, S D=1.95544)$ and female teachers, $M=11.8786, S D=2.22629 ; t(.969)=198, p=.334$. There was no significant difference in teaching discipline scores for male $(M=19.6833, S D=3.17560)$ and female teachers, $M=19.2500, S D=3.57474 ; t(.812)$ $=198, p=.418$. There was no significant difference in teaching guidance scores for male $(M=16.0667, S D=$ $2.19295)$ and female teachers, $M=15.5929, S D=3.28041 ; t(1.196)=162.852, p=.234$ and there was no significant difference in external matters scores of male $(M=11.3667, S D=2.33591)$ and female teachers, $M=$ $11.3643, S D=2.61487 ; t(.006)=198, p=.995$. It is concluded that prospective teachers have no difference regarding efficacy factors in their opinions on the basis of gender.

Table 7

One Way ANOVA to check Difference about Teaching Efficacy on the Basis of Teachers' Age

\begin{tabular}{|c|c|c|c|c|c|c|}
\hline Factors & & Sum of Squares & $d f$ & Mean Square & $F$ & Sig. \\
\hline \multirow[t]{3}{*}{ Instruction } & Between Groups & 20.521 & 2 & 10.260 & 2.250 & .108 \\
\hline & Within Groups & 898.354 & 197 & 4.560 & & \\
\hline & Total & 918.875 & 199 & & & \\
\hline \multirow[t]{3}{*}{ Discipline } & Between Groups & 20.586 & 2 & 10.293 & .860 & .425 \\
\hline & Within Groups & 2358.534 & 197 & 11.972 & & \\
\hline & Total & 2379.120 & 199 & & & \\
\hline \multirow[t]{3}{*}{ Guidance } & Between Groups & 79.462 & 2 & 39.731 & 4.579 & .011 \\
\hline & Within Groups & 1709.493 & 197 & 8.678 & & \\
\hline & Total & 1788.955 & 199 & & & \\
\hline \multirow[t]{3}{*}{ External } & Between Groups & 17.963 & 2 & 8.982 & 1.411 & .246 \\
\hline & Within Groups & 1254.392 & 197 & 6.367 & & \\
\hline & Total & 1272.355 & 199 & & & \\
\hline
\end{tabular}

Table represents that one-way ANOVA was applied to know the difference in mean scores of teaching instruction teaching discipline, teaching guidance, external matters and teaching efficacy on the basis of their age. Results show that there was no difference in mean scores of teachers regarding teaching instruction $F(2,197)=$ 2.250 at $p=.108$; teaching discipline $F(2,197)=.860$ at $p=.425$; there was difference in teachers perceptions regarding teaching guidance $F(2,197)=4.579$ at $p=.011$. And there was no significant difference in mean scores of teachers about external matters $F(2,197)=1.411$ at $p=.246$. It is concluded that teachers have no difference in mean scores regarding teaching instruction teaching discipline, external matters and teaching 
efficacy based on age difference. But they have difference in teaching guidance.

Table 8

One Way ANOVA to check Teachers' Qualification Difference about Teaching Efficacy

\begin{tabular}{|c|c|c|c|c|c|c|}
\hline Factors & & Sum of Squares & $d f$ & Mean Square & $F$ & Sig. \\
\hline \multirow[t]{3}{*}{ Instruction } & Between Groups & 14.860 & 2 & 7.430 & 1.619 & .201 \\
\hline & Within Groups & 904.015 & 197 & 4.589 & & \\
\hline & Total & 918.875 & 199 & & & \\
\hline \multirow[t]{3}{*}{ Discipline } & Between Groups & 2.934 & 2 & 1.467 & .122 & .886 \\
\hline & Within Groups & 2376.186 & 197 & 12.062 & & \\
\hline & Total & 2379.120 & 199 & & & \\
\hline \multirow[t]{3}{*}{ Guidance } & Between Groups & 1.143 & 2 & .572 & .063 & .939 \\
\hline & Within Groups & 1787.812 & 197 & 9.075 & & \\
\hline & Total & 1788.955 & 199 & & & \\
\hline \multirow[t]{3}{*}{ External } & Between Groups & 23.966 & 2 & 11.983 & 1.891 & .154 \\
\hline & Within Groups & 1248.389 & 197 & 6.337 & & \\
\hline & Total & 1272.355 & 199 & & & \\
\hline
\end{tabular}

Table indicates that one-way ANOVA was applied to know the difference in mean scores of teachers regarding teaching instruction teaching discipline, teaching guidance, external matters and teaching efficacy on the basis of their qualification. Findings show that there was no difference in mean scores of teachers regarding teaching instruction $F(2,197)=1.619$ at $p=.201$; teaching discipline $F(2,197)=.122$ at $p=.886$; there was difference in teachers perceptions regarding teaching guidance $F(2,197)=.063$ at $p=.939$. And there was no significant difference in mean scores of teachers about external matters $F(2,197)=1.891$ at $p=.154$. It is concluded that teachers have no difference in mean scores regarding teaching instruction teaching discipline, external matters, teaching guidance, and teaching efficacy based on qualification difference.

\section{Conclusion}

The study was examined the teaching efficacy among prospective teachers with the help of different factors of efficacy. Researchers examined the perceptions of prospective teachers' efficacy in this study. Majority of the prospective teachers showed high level of teaching efficacy. They said they have a good grasp of teaching approaches that help them to maintain students' learning motivation. Their teaching methods are very effective in helping students to learn more. They know how to teach a new concept so that students will master it quickly. They are effective in making rules and regulations to maintain discipline in the classrooms. They have management skills and they manage their classrooms effectively. They understand students' psychological needs easily. They are also able to help students to manage emotional problems in life. Research respondents said that to maintain discipline in classroom is a difficult task. And they face problems to maintain discipline. It is concluded that there was no significant difference between male and female prospective teachers efficacy. The male and female teachers both have same level of teaching efficacy. There was no significant difference among teacher efficacy on the basis of age. It is confirmed that teachers have no difference in mean scores regarding teaching instruction teaching discipline, external matters, teaching guidance, and teaching efficacy based on qualification difference.

\section{Recommendations}

This study has number of implication to manage teacher efficacy among prospective teachers. Due to advancement in technology and high competition there is a race among institutes and teachers. This study shows that if the teachers enhance teaching efficacy then they perform well. In Pakistan, teachers need to set rules and regulation for time management, policies for compensation, training of managing work related tasks and create a supportive environment to increase efficacy level.

1. School education department may promote discipline in the classroom. Teachers may give more authority to maintain discipline.

2. Prospective teachers may trained in psychological aspects. Then they read the mind of students because good teachers understand the students psyche easily.

3. Communication is important in education. Prospective teachers may focus on communication skills.

4. Prospective teachers may focus on teaching methods and deliver lectures and content by adopting relevant methods.

\section{References}

Bandura, A. (1986a). Social foundations of thought and action: A social cognitive theory. Englewood Cliffs, NJ: Prentice-Hall. 
Bandura, A. (1986b). The explanatory and predictive scope of self-efficacy theory. Journal of Clinical and Social Psychology, 4, 359-373.

Bandura, A. (1997). Self-efficacy: The exercise of control. New York: Freeman.

Barkley, J. M. (2006). Reading education: Is self-efficacy important? Reading Improvement, 43(4), $194-219$.

Lee, G. H. (2002). The development of teacher efficacy beliefs. In J. J. Irvine (Ed.), In search of wholeness: African-American teachers and their culturally specific classroom practices (pp. 67-85). New York: PALGRAVE.

Miskel, C., McDonald, D., \& Bloom, S. (1983). Structural and expectancy linkages within schools and organizational effectiveness. Educational Administration Quarterly, 19(1), 49-82.

Ross, J., \& Bruce, C. (2007). Professional development effects on teacher efficacy: Results of randomized field trial. The Journal of Educational Research, 101(1), 50-60.

Tucker, C. M., Porter, T., Reinke, W. M., Herman, K. C., Ivery, P. D., \& Mack, C. E. et al. (2005, Fall). Promoting teacher efficacy for working with culturally diverse students. Preventing School Failure, 50, 2934. 